\title{
ERRATUM
}

\section{Erratum to: Evaluation of the Performance of Portable New Design High DC Voltage Measuring System up to $40 \mathrm{kV}$}

\author{
A. Merev*, S. Dedeoglu and K. Gülnihar
}

TUBITAK UME (National Metrology Institute of Turkey), Gebze Yerleskesi, P.O. Box 54, 41470 Kocaeli, Turkey

Published online: 27 July 2014

(C) Metrology Society of India 2014

\section{Erratum to: MAPAN}

DOI 10.1007/s12647-014-0100-6

In the original publication of the article, the title and author group was published erroneously. The corrected title and author group of the article are given in this erratum.

The online version of the original article can be found under doi:10.1007/s12647-014-0100-6.

*Corresponding author, E-mail: ahmet.merev@tubitak.gov.tr 